\title{
Suppression of Common Scab of Potato Caused by Streptomyces turgidiscabies Using Lopsided Oat Green Manure
}

F. Sakuma, Snow Brand Seed Co., Ltd., Hokkaido Research Station, 1066, Horonai, Naganuma-cho, Yubari-gun, Hokkaido, 069-1464, Japan, and Plant Pathology Department, Hokkaido University, Kita 9, Nishi 9, Kita-ku, Sapporo 060-8589, Japan; M. Maeda, Niigata Agricultural Research Institute, 857, Nagakura-cho, Nagaoka-city, Niigata, 940-0826, Japan; M. Takahashi, Snow Brand Seed Co., Ltd., Hokkaido; K. Hashizume, Snow Brand Seed Co., Ltd., Chiba Research Station, 634, Naganumahara-cho, Inage-ku, Chiba, 2630001, Japan; and N. Kondo, Plant Pathology Department, Hokkaido University, Sapporo

\begin{abstract}
Sakuma, F., Maeda, M., Takahashi, M., Hashizume, K., and Kondo, N. 2011. Suppression of common scab of potato caused by Streptomyces turgidiscabies using lopsided oat green manure. Plant Dis. 95:1124-1130.

Field experiments were conducted to determine the effect of green manure as fallow on common scab of potato caused by Streptomyces turgidiscabies. Significantly fewer diseased tubers were harvested from soil incorporated with lopsided oat or woolly pod vetch compared with those from oat and continuous potato cultivation in a planter experiment. Each field experiment consisted of lopsided oat cultivated during the spring and summer prior to the potato planting. Comparisons were also made with several other treatments, including cultivation of woolly pod vetch, oat, soybean, sugar beet, and potato ('Yukirasya', which is resistant to potato common potato scab) and soil application of Ferosand (Fe, mainly $\mathrm{FeSO}_{4}$, to decrease the soil $\mathrm{pH}$ ). In field experiments conducted during 1999-2000, treatment with lopsided oat followed by lopsided oat or woolly pod vetch was significantly more effective at suppressing the disease severity than oat and continuous potato cultivation $(P<0.001)$. An increase in the marketable tuber ratio

was also more significant than for oat and continuous potato cultivation $(P<0.001)$. In field experiments conducted during $2000-01$, lopsided oat cultivation alone and with the application of Ferosand $(1.8 \mathrm{t} / \mathrm{ha})$ or resistant potato cultivar treatment were significantly more effective at suppressing the disease severity and incidence than sugar beet cultivation $(P<0.001)$, even under high disease intensity in the field. However, potato yield had a tendency to reduce after lopsided oat treatment with an application of Ferosand (1.8 t/ha) compared with lopsided oat alone or the application of Ferosand at $600 \mathrm{~kg} / \mathrm{ha}$, due to low $\mathrm{pH}$ conditions. In field experiments conducted during 2001-02, the lowest severity and incidence of common scab of potato were observed in soil treated with lopsided oat than with other treatments $(P<0.05$ and $P<$ 0.001 , respectively). These findings suggest that lopsided oat used as fallow green manure can reduce the severity of common scab and increase potato yield.
\end{abstract}

Common scab is a disease of major economic importance in most potato-producing areas of the world (17). The disease, caused mainly by Streptomyces scabies, S. turgidiscabies, and S. acidiscabies $(17,23)$, poses a problem to potato production because it may persist in soil or on plant residues for up to 10 years (16). There are two major causal pathogens of potato common scab (PCS) in Hokkaido, (the northern island of Japan): S. scabies and S. turgidiscabies. The former is dominant in the western area, which includes the Hidaka mountain range, while the latter dominates in the east (40). Tubers from infested sites are often unmarketable and, for some growers, the disease has become a limiting factor in production.

The development of resistant potato cultivars began in Japan in 1990 (13) but susceptible cultivars such as 'Danshakuimo' ('Irish Cobbler') have been widely cultivated for table stock in Japan, due to appealing taste and tendency to mature early (12). Control of the disease using chemicals has not been attempted in Hokkaido except for part of an area in Kyushu, the southern island of Japan, in which soils were maintained at a pH 4.5 to 4.8 and disinfested with chloropicrin. However, this treatment is economically unviable in the Hokkaido area, because farmers have very large fields and must cultivate rotation crops such sugar beet, which are susceptible to a low $\mathrm{pH}$ (37). Indeed, the substantial application of immature organic matter to areas with neutral to weakly alkaline soil predisposes them to severe disease. Therefore, farmers have avoided

Corresponding author: F. Sakuma, E-mail: futoshi.sakuma@snowseed.co.jp Accepted for publication 28 April 2011.

doi:10.1094/PDIS-08-10-0615

(C) 2011 The American Phytopathological Society composting and continue operations with a lower soil $\mathrm{pH}$ (5.0 to $5.5)$ before potato production, leading to maintenance of soil acidity and an appropriate level of soil fertility.

Green manures provide substantial benefits to the soil by increasing organic matter and nutrients to improve soil structure and control weeds $(1,2)$. Furthermore, green manure suppresses soilborne diseases $(6,26)$. Many types of plants have been used as green manure in Hokkaido. In particular, the lopsided oat cultivar 'Hayoats' (Avena strigosa Schreb.) has been widely used as a green manure crop because it is high yielding, has rich root systems, and decomposes easily. Additionally, this plant suppresses the root lesion nematode Pratylenchus penetrans in soil (45).

The objective of this study was to screen green manure crops for the ability to suppress PCS and to determine the effects of green manure crops (especially lopsided oat) on PCS in commercial fields. To meet this objective, one planter experiment for screening green manures and three 2-year field trials were conducted in which green manure and rotation crops were tested. We also evaluated the suppression of PCS using lopsided oat treatment with Ferosand ( $\mathrm{FeSO}_{4}$ used to adjust soil $\mathrm{pH}$ ) and a potato cultivar resistant to common scab in a high-disease-intensity field.

\section{Materials and Methods}

We carried out one planter experiment and three field experiments, and succinctly summarized the treatments and details of each of the four experiments in Table 1 .

Planter experiment. Plastic containers ( 33 by 55 by $33 \mathrm{~cm}$ ) were filled with soil (two replications) from fields containing common scab and were buried in a field at the Snow Brand Seed Co. Ltd., Hokkaido Research Station $\left(42^{\circ} 55^{\prime} \mathrm{N}, 141^{\circ} 43^{\prime} \mathrm{E}\right)$. The green manure crops were lopsided oat (A. strigosa, $150 \mathrm{~kg} / \mathrm{ha}$; 'Hayoats'), woolly pod vetch (Vicia villosa, $50 \mathrm{~kg} / \mathrm{ha}$; 'Mamesuke'), white mustard (Sinapis alba, 20 kg/ha; 'Kikarashi'), 
common oat (A. sativa, $150 \mathrm{~kg} / \mathrm{ha}$; 'Tochiyutaka'), and crimson clover (Trifolium incarnatum, $20 \mathrm{~kg} / \mathrm{ha}$; 'Kurenai'). The crops were sown in containers twice (mid-May and mid-August 1996). Potato (Dansyakuimo, two tubers per container) was cultivated in 1996 according to standard practices. $\mathrm{N}, \mathrm{P}$, and $\mathrm{K}$ fertilizer at $50 \mathrm{~kg} / \mathrm{ha}$ was applied for the green manure crops and potato at each sowing time. Green manure crops were incorporated into the soil by shovel in mid-July and late October 1996, and potato tubers were harvested and removed from the containers in late September 1996. All containers were sown for potato ('Dansyakuimo', two tubers per container) at the beginning of May 1997 and managed according to standard practices.

Fields trials. The fields used in this investigation were located in the towns of Shihoro (1999-2000, 2001-02; and field experiments 1 and 3) and Kiyosato (2000-01 and field experiment 2) in Hokkaido. These fields had a history of moderate to heavy PCS. N, $\mathrm{P}$, and $\mathrm{K}$ fertilizer at $50 \mathrm{~kg} / \mathrm{ha}$ were applied for the green manure at each sowing time, and $100 \mathrm{~kg} / \mathrm{ha}$ each for sugar beet, soybean, and potato were used for rotation crops.

Plots (6 by $14 \mathrm{~m}$ ) were arranged in a randomized block design with two replicates in field experiment 1 . Green manure crops were sown twice (18 May and 11 August 1999). Lopsided oat (150 kg/ha; 'Hayoats'), woolly pod vetch ( $50 \mathrm{~kg} / \mathrm{ha}$; 'Mamesuke'), and common oat ( $150 \mathrm{~kg} / \mathrm{ha}$; 'Suwan') were sown by hand in each plot and raked into the soil. Lopsided oat was sown on 11 August 1999 after cultivation of woolly pod vetch plots. Potato ('Dansyakuimo' cut seed pieces with no visible scab symptoms) was cultivated in 1999 according to standard practices. Green manure crops were incorporated into the soil with a rotovator on 23 July and 12 October 1999, and potato tubers were harvested and removed from the field on 12 October 1999. All plots were sown with potato ('Dansyakuimo', 72-cm rows, $36 \mathrm{~cm}$ within-row spacing) on 10 May 2000 and managed according to standard practices.

Plots $(4$ by $6.6 \mathrm{~m}$ ) were arranged in a randomized block design with three replicates in field experiment 2. Lopsided oat was sown by hand on 25 May and 16 August 2000 and raked into the soil. Lopsided oat was incorporated into the soil with a rotovator in late July and mid-October 2000. Sugar beet was cultivated in 2000 according to standard practice. Sugar beet was harvested in late October 2000 and the residue was incorporated into the soil. On 16 May 2001, plots were sown with potato ('Konafubuki', 66-cm rows, $36 \mathrm{~cm}$ within-row spacing) and managed according to standard practices. Because disease intensity is very high in this region, the cultivar used for starchy substrate is widely cultivated. Because of a seriously disease-infested area, Ferosand (containing 93.4\% $\mathrm{FeSO}_{4}$; Ishihara Techno Corp., Osaka, Japan) was applied to adjust the soil $\mathrm{pH}$ and exchange acidity in the lopsided oat and sugar beet plots before planting potato. A standard volume of Ferosand was used by broadcasting ( $3.6 \mathrm{t} / \mathrm{ha}$ ) to adjust the soil $\mathrm{pH}$ to 5.0 . Next, Ferosand at $1.8 \mathrm{t} / \mathrm{ha}$ or $600 \mathrm{~kg} / \mathrm{ha}$ was used in rows. Also, 'Yukirasya', a potato cultivar resistant to common scab, was planted in three plots after lopsided oat treatment.

Plots $(4$ by $8 \mathrm{~m}$ ) were arranged in a randomized block design with three replicates in field experiment 3 . Green manure crops were sown on 24 May and 7 August 2001. Lopsided oat and com- mon oat were sown by hand in plots and raked into the soil. Potato 'Norin no. 1' and soybean 'Toiku 235' were sown in 2001 according to standard practices. Green manure was incorporated into the soil with a rotovator on 28 July and 5 October 2001. Potato tubers were harvested and removed from the field. Soybean was harvested and the residue was incorporated into the soil. On 13 May 2002, the plots were sown for potato ('Dansyakuimo', 72-cm rows, 36-cm withinrow spacing) and managed according to standard practices.

Disease assessment. All potato tubers were dug from each container of the planter experiment. During the second year of the allfield trial, tubers were sampled from 15 potato plants randomly selected from the middle part of each plot. All harvested tubers were rinsed with water, weighed, and rated for scab. The severity of scab symptoms was recorded on a 0 -to- 4 ordinal scale, where 0 $=$ no scab lesions and $1=1$ to $3,2=4$ to $10,3=11$ to 20 , and $4=$ $>21$ lesions/tuber. The disease severity of scab was represented as a proportion and calculated as follows: (the sum of the number of tubers in a category $\times$ category) $/ 4 \times$ (total number of scored tubers). The disease incidence was expressed as the percentage of tubers with scab symptoms (scab index $=1$ to 4 ) in each plot. Marketable tubers were defined as the percentage of tubers with a scab index of 0 or 1 , which is acceptable for fresh-market table stock or processing. Tubers weighing more than $20 \mathrm{~g}$ were used for disease assessments and yield data in all experiments.

Soil assay. Soil samples were collected from each plot for soil $\mathrm{pH}$ and exchange acidity (y1) testing prior to potato planting during the spring, prior to the application of preplant fertilizers, and at the time of potato harvest in the field experiments. The tests were performed on a minimum of six soil cores per plot after pooling. The samples were air dried and ground before analysis. The soil $\mathrm{pH}$ in water was measured in a water suspension of each soil sample using a soil solution ratio of $1: 2.5$. The y1 was measured by titrating a $1 \mathrm{M} \mathrm{KCl}$ soil extract with $0.1 \mathrm{M} \mathrm{NaOH}$ (34). Soil samples were stored at $4^{\circ} \mathrm{C}$ until they were processed to investigate pathogen density as described below. In preliminary experiments, we confirmed $S$. turgidiscabies as the causal agent of potato scab in these experimental areas. Soil samples were assayed by a dilution plating method using semiselective medium and by polymerase chain reaction (PCR) using primers specific for $S$. turgidiscabies to investigate the soil density of the microbe following the field experiments (40). Semiselective medium consisted of soluble potato starch, $5.0 \mathrm{~g}$; yeast extract (Difco Laboratories, Detroit), $4.0 \mathrm{~g}$; bacto peptone (Difco Laboratories), $0.6 \mathrm{~g}$; protease peptone number 3 (Difco Laboratories), $0.6 \mathrm{~g}$; NaCl, $10 \mathrm{~g} ; \mathrm{K}_{2} \mathrm{HPO}_{4}, 1.0 \mathrm{~g}$; $\mathrm{MgSO}_{4} \cdot 7 \mathrm{H}_{2} \mathrm{O}, 0.5 \mathrm{~g}$; agar, $17 \mathrm{~g}$; and $1 \mathrm{ml}$ of a stock microelement solution comprising $10 \mathrm{mg}$ of $\mathrm{FeSO}_{4}, 1 \mathrm{mg}$ of $\mathrm{ZnSO}_{4}$, and $1 \mathrm{mg}$ of $\mathrm{MnCl}$, dissolved in distilled $\mathrm{H}_{2} \mathrm{O}$. The $\mathrm{pH}$ of the medium was 7.2. Cycloheximide $(200 \mu \mathrm{g} / \mathrm{ml})$, nystatin $(5.6 \mu \mathrm{g} / \mathrm{ml})$, sodium dehydroacetate $(1,000 \mu \mathrm{g} / \mathrm{ml})$, lithium chloride $(5,000 \mu \mathrm{g} / \mathrm{ml})$, nalidixic acid $(15 \mu \mathrm{g} / \mathrm{ml})$, and meticillin $(0.5 \mu \mathrm{g} / \mathrm{ml})$ were added after sterilization by autoclave. Candidate colonies that were yellow in color were isolated on the semiselective medium for 2 weeks at $25^{\circ} \mathrm{C}$ and then transferred on starch medium (soluble potato starch, 10.0 g; sucrose, $1.0 \mathrm{~g}$; yeast extract, $1.0 \mathrm{~g} ; \mathrm{NaNO}_{3}, 0.1 \mathrm{~g} ; \mathrm{MgSO}_{4} \cdot 7 \mathrm{H}_{2} \mathrm{O}$, $0.1 \mathrm{~g} ; \mathrm{KH}_{2} \mathrm{PO}_{4}, 0.1 \mathrm{~g} ; \mathrm{KCl}, 0.1 \mathrm{~g}$; and agar, $15.0 \mathrm{~g}$; the $\mathrm{pH}$ of the

Table 1. List of treatments and details of each of the four experiments

\begin{tabular}{|c|c|c|c|}
\hline Experiment & Objective $^{y}$ & First season $^{z}$ & Second season \\
\hline Planter & Screening green manures to control PCS & $\begin{array}{l}\text { Lopsided oat (2), woolly pod vetch (2), } \\
\text { white mustard (2), oat (2), crimson clover } \\
\text { (2), potato }\end{array}$ & Potato ('Danshakuimo') \\
\hline Field 1 & $\begin{array}{l}\text { Confirmation of green manures to control PCS in field } \\
\text { level }\end{array}$ & $\begin{array}{l}\text { Lopsided oat (2), wooly pod vetch and } \\
\text { lopsided oat, oat (2), potato }\end{array}$ & (Dansyakuimo) \\
\hline Field 2 & $\begin{array}{l}\text { Assessment combination Ferosand or potato resistant } \\
\text { variety with lopsided oat and comparison of lopsided } \\
\text { oat with sugar beet in high disease intensity area }\end{array}$ & (2), sugar beet & $\begin{array}{l}\text { Potato ('Konafubuki', 'Yukirasya': } \\
\text { PCS resistant cultivar) and Ferosand } \\
(1.8 \mathrm{t} / \mathrm{ha} \text { or } 600 \mathrm{~kg} / \mathrm{ha})\end{array}$ \\
\hline Field 3 & Comparison of lopsided oat with soybean & Lopsided oat (2), oat (2), soybean, potato & Potato (Dansyakuimo) \\
\hline
\end{tabular}

y $\mathrm{PCS}=$ potato common scab.

${ }^{\mathrm{z}}$ Number in parentheses indicate the number of planting times. 
medium was adjusted to 8.0) (21) for 5 days at $28^{\circ} \mathrm{C}$. To prepare the template DNA fraction, mycelia were picked up from candidate colonies that were gray in color with a filamentous spore chain, suspended in $20 \mu \mathrm{l}$ of distilled water in a $1.5-\mathrm{ml}$ tube, vortexed, centrifuged, and heated for $10 \mathrm{~min}$ at $95^{\circ} \mathrm{C}$, then cooled at room temperature. The DNA was stored at $-20^{\circ} \mathrm{C}$ until amplified by PCR. PCR was performed in a total volume of $20 \mu \mathrm{l}$ containing 5 $\mu \mathrm{l}$ of extracted DNA, $2 \mu \mathrm{l}$ of $10 \times$ buffer (Nippon Gene Co., Ltd., Toyama, Japan), $1.6 \mu \mathrm{l}$ of $250 \mu \mathrm{M}$ each dNTP, $0.5 \mu \mathrm{l}(20 \mathrm{pmol}$ each) of the primers TU-02 (5' GGA AAC ATC CAG AGA TGG GTG 3') and TU-01 (5' GAC AGT ACT GGA AGG AGA AGA C $\left.3^{\prime}\right), 0.5 \mu \mathrm{l}$ of $10 \%$ skim milk solution, and $0.1 \mu \mathrm{l}$ of Taq polymerase. PCR was performed on a Takara PCR Thermal Cycler MP. The cycling program consisted of an initial step of $2 \min 30 \mathrm{~s}$ at $95^{\circ} \mathrm{C}$, followed by 35 cycles of denaturation at $95^{\circ} \mathrm{C}$ for $1 \mathrm{~min}$, annealing at $65^{\circ} \mathrm{C}$ for $1 \mathrm{~min}$, and elongation at $72^{\circ} \mathrm{C}$ for $2 \mathrm{~min}$. A final extension was performed at $72^{\circ} \mathrm{C}$ for $5 \mathrm{~min}$. The products were separated on $1.5 \%$ agarose gels (Nippon Gene Co.), stained with ethidium bromide, and visualized under a UV light to confirm the presence of a 686-bp product. A 100-bp DNA ladder was used as a molecular size marker (Takara Bio Inc., Shiga, Japan).

Data analysis. All statistical analyses were performed using the $\mathrm{R}$ statistical environment for statistical computing and graphics, version 2.9.2. (32). S. turgidiscabies soil density data were normalized using a $\log _{10}(x+1)$ transformation, with $x$ equal to the average number of propagules per gram of dry soil. Spearman rank correlations between scab disease incidence and soil properties or pathogen density were determined.

Potato yield, $S$. turgidiscabies soil density, $\mathrm{pH}$, and exchange acidity were analyzed with a linear mixed model (9). Treatment and block were treated as fixed and random effects, respectively. This analysis and parameter estimations were performed using restricted maximum likelihood with the nlme package (30). Significant differences among these estimated linear parameters for potato yield, pathogen density, $\mathrm{pH}$, and exchange acidity were separated using Tukey's pairwise comparison with the multcomp package (11). Confidence intervals (CIs) were calculated for these models with the multcomp package (11).

Scab severity was recorded on a categorical basis as ordinal data using multiple scales for each experiment. Because only two potato plants were used in each container in the planter experiment, we surveyed after all tubers within replications for each treatment had been mixed. For the planter experiment, disease severity classes were treated as an order factor, which was modeled with a proportional odds model, after which treatment (green manure crops) was incorporated as an explanatory variable $(3,7,8,28)$ using the VGAM package (47). Our results are presented as the log of the odds ratio with the $\log$ of the $95 \% \mathrm{CI}$ estimates, using oat treatment as the zero baseline. Because disease severity, disease incidence, and the rate of marketable tubers were proportional data (from 0 to 1 ) and characterized by a binomial distribution, a generalized liner mixed model (GLMM) was used for these data $(5,20)$. Treatments and blocks were treated as fixed and random effects, respectively. Fitting of the GLMM to the data was done using the Laplace approximation with the lme4 package (4). Significant differences among these estimated linear parameters for disease severity, disease incidence, and the rate of marketable tubers were separated using Tukey's pairwise comparison with the multcomp package. CIs were calculated with the multcomp package using a linear mixed model.

\section{Results}

Planter experiment. The log of the odds ratios and 95\% CIs for the ordinal logistic regression model are given in Figure 1. Positive parameters are interpreted as increasing the probability of lowlevel classes of disease-severity classes. The odds ratios for disease severity using lopsided oat and woolly pod vetch were significantly lower than for oat treatment. In contrast, disease level in soil amended with continuous potato cultivation was promoted significantly relative to oat treatment.

Field trials. Lopsided oat or woolly pod vetch cultivation followed by lopsided oat was more effective for suppressing PCS than oat and continuous potato cultivation in field experiment 1 (Table 2). Disease severity in the lopsided oat or woolly pod vetch plots with subsequent lopsided oat cultivation was significantly lower than for oat $(P<0.001)$ and continuous potato treatment $(P<$ 0.001). Furthermore, the disease incidences in the lopsided oat or vetch plots followed by lopsided oat were lower than for oat $(P=$ 0.319 and $P<0.001$, respectively) and continuous potato treatment ( $P=0.007$ and $P<0.001$, respectively). The proportion of marketable tubers in the lopsided oat and woolly pod vetch plots were 65.3 and $74.0 \%$, respectively, which is significantly higher

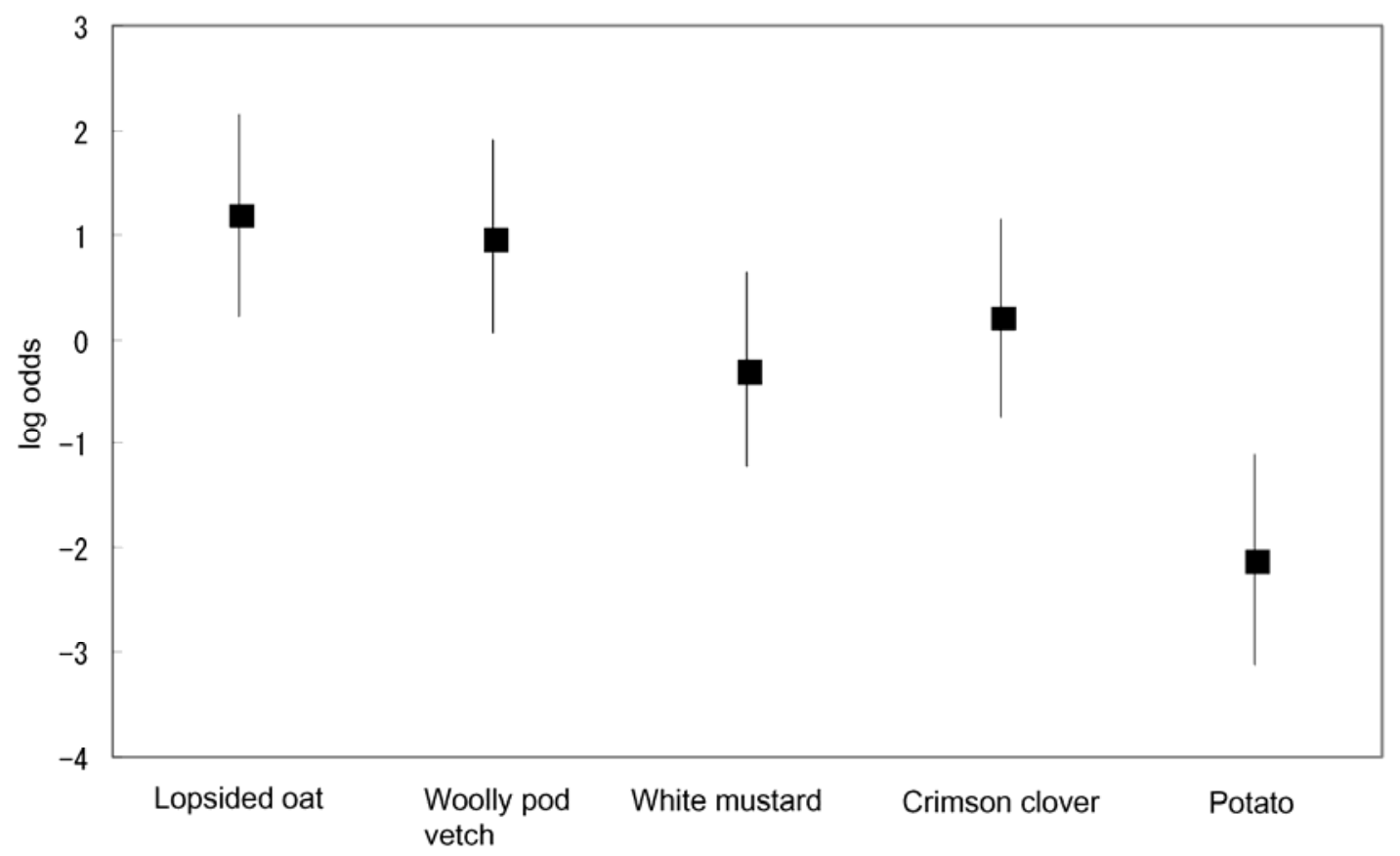

Fig. 1. Log of the disease severity odds ratios for the planter experiment. Results for each treatment were compared with those for oat. Black squares indicate the log of the odds ratio, while vertical lines indicate the $95 \%$ confidence interval for the estimates. Vertical lines intercepting the zero baseline are not significantly different from oat treatment. 
than for the oat $(P<0.001)$ and continuous potato $(P<0.001)$ treatments. The total potato yield and $S$. turgidiscabies soil density in soil at harvest were not statistically different between treatments, although the potato yield tended to increase and pathogen density tended to decrease in plots previously cropped with lopsided oat compared with the other treatments. The relationship between $S$. turgidiscabies density and disease incidence was significantly correlated ( $\rho=0.79, P=0.02$; Table 3$)$. Treatment effects on soil $\mathrm{pH}$ and exchange acidity were variable at the time of soil sampling (Table 4). Before potato planting, soil collected from a lopsided oat field with subsequent lopsided oat treatment had a significantly higher $\mathrm{pH}$ than oat-treated soil. No treatment had a significant effect on $\mathrm{pH}$ at potato harvest. However, the soil exchange acidities before planting were not significantly different among treatments. At potato harvest, the soil exchange acidity for lopsided oat followed by lopsided oat treatment was significantly higher than for the other treatments. The disease incidence in individual plots was not associated with soil $\mathrm{pH}$ or exchange acidity at any sampling time (Table 3 ).

In experiment 2 at Kiyosato, lopsided oat treatments were combined with Ferosand or resistant cultivars, because the field was heavily infested. Preplant cultivation (lopsided oat and sugar beet) affected the disease level in the subsequent potato plants (Table 5). Disease severity following lopsided oat treatment was $15.2 \%$, which is significantly lower than following treatment with sugar beet $(P<0.001)$, which is a common rotation crop. Disease incidence following lopsided oat treatment was $47.3 \%$, which is significantly lower than following sugar beet treatment $(P<0.001)$. Thus, lopsided oat treatment produced a higher marketable tuber ratio than sugar beet treatment. Moreover, one-sixth of the control volume of Ferosand $(600 \mathrm{~kg} / \mathrm{ha})$ decreased the disease severity and incidence and increased the marketable tuber ratio in the lopsided oat plots, with the reduction in disease severity and incidence falling to $41 \%$ compared with lopsided oat alone; however, no effect was observed in sugar beet plots. Furthermore, lopsided oat treatment with one-half of the Ferosand control $(1.8 \mathrm{t} / \mathrm{ha})$ or a resistant cultivar was more effective than treatment with lopsided oat alone, with a decrease in disease incidence falling to 66 and $89 \%$, respectively. The soil $\mathrm{pH}$ and exchange acidity were slightly different among the treatments before potato planting but the exchange acidity rose in the Ferosand-treated plots at potato harvesting time (Table 4). The disease incidence in individual plots was significantly associated with soil $\mathrm{pH}(\rho=0.72, P<0.01)$ at potato preplanting or with exchange acidity $(\rho=-0.63, P<0.01)$ at harvesting (Table 3$)$.

Table 2. Effect of green manure treatment on common potato scab in field experiment $1(1999-2000)^{\mathrm{x}}$

\begin{tabular}{|c|c|c|c|c|c|}
\hline Treatment $^{\mathrm{y}}$ & $\begin{array}{c}\text { Disease severity } \\
(\%)\end{array}$ & $\begin{array}{c}\text { Disease incidence } \\
(\%)\end{array}$ & $\begin{array}{c}\text { Marketable tuber } \\
(\%)\end{array}$ & $\begin{array}{c}\text { Potato yield } \\
\left(\mathbf{t ~ h a}^{-1}\right)\end{array}$ & $\begin{array}{c}\text { Streptomyces } \\
\text { turgidiscabies density }\end{array}$ \\
\hline $\mathrm{LO} / \mathrm{LO}$ & $29.8(23.4,37.1) b$ & $81.9(63.2,92.3) b$ & $65.3(54.6,74.7) \mathrm{a}$ & $32.5(24.3,40.6) \mathrm{a}$ & $3.58(3.01,4.14) \mathrm{a}$ \\
\hline $\mathrm{V} / \mathrm{LO}$ & $23.5(17.7,30.4) \mathrm{c}$ & $67.0(43.8,84.1) \mathrm{c}$ & $74.0(62.7,82.8) \mathrm{a}$ & $28.5(20.4,36.6)$ a & $3.54(2.97,4.10) \mathrm{a}$ \\
\hline $\mathrm{O} / \mathrm{O}$ & $40.5(32.8,48.6) \mathrm{a}$ & $88.2(72.7,95.5) \mathrm{ab}$ & $42.7(31.9,54.3) b$ & $23.7(15.6,31.8) \mathrm{a}$ & $3.82(3.25,4.38) \mathrm{a}$ \\
\hline $\mathrm{P}$ & $43.5(34.8,52.6) \mathrm{a}$ & $95.6(84.2,98.9) \mathrm{a}$ & $31.9(20.5,45.9) b$ & $26.9(18.7,35.0) \mathrm{a}$ & $3.92(3.35,4.48) \mathrm{a}$ \\
\hline
\end{tabular}

${ }^{\mathrm{x}}$ Within-factors for each response variable followed by the same letter are not significantly $(P>0.05)$ different according to Tukey's pairwise comparison.

Point estimates in parentheses indicate $95 \%$ confidence intervals.

y Precrops in 1999 before potato. LO, lopsided oat; V, woolly pod vetch; O, oat; P, potato.

${ }^{\mathrm{z}} \log _{10}(x+1)$ transformation; $x=\mathrm{CFU} / \mathrm{g}$ dry soil.

Table 3. Spearman rank correlations between scab disease incidence and soil $\mathrm{pH}$, exchange acidity (y1), and pathogen (Streptomyces turgidiscabies) density in all field experiments ${ }^{z}$

\begin{tabular}{|c|c|c|c|c|c|}
\hline \multirow[b]{2}{*}{ Experiment } & \multicolumn{2}{|c|}{$\mathbf{p H}$} & \multicolumn{2}{|c|}{ y1 } & \multirow[b]{2}{*}{ Pathogen density in soil } \\
\hline & Pre & Post & Pre & Post & \\
\hline Field experiment 1 & -0.16 & -0.62 & -0.26 & -0.43 & $0.79 *$ \\
\hline Field experiment 2 & $0.72 * *$ & 0.30 & -0.01 & $-0.63 * *$ & 0.58 \\
\hline Field experiment 3 & 0.13 & 0.14 & -0.20 & -0.56 & 0.62 \\
\hline
\end{tabular}

${ }^{\mathrm{z}}$ Asterisks: $*$ and $* *$ indicate significant at the 0.05 and 0.01 probability level, respectively.

Table 4. $\mathrm{pH}$ and exchange acidity (y1) in all field studies ${ }^{\mathrm{y}}$

\begin{tabular}{|c|c|c|c|c|}
\hline \multirow[b]{2}{*}{ Study, treatment ${ }^{z}$} & \multicolumn{2}{|c|}{ pH } & \multicolumn{2}{|c|}{ y1 } \\
\hline & Pre & Post & Pre & Post \\
\hline \multicolumn{5}{|l|}{ Field 1} \\
\hline $\mathrm{LO} / \mathrm{LO}$ & $5.47(5.34,5.59) \mathrm{a}$ & $5.76(5.46,6.06) \mathrm{a}$ & $1.57(0.69,2.44) \mathrm{a}$ & $3.69(2.76,4.62) \mathrm{a}$ \\
\hline V/LO & $5.35(5.23,5.48) a b$ & $5.79(5.48,6.09) \mathrm{a}$ & $1.25(0.38,2.13) \mathrm{a}$ & $1.88(0.95,2.81) b$ \\
\hline $\mathrm{O} / \mathrm{O}$ & $5.26(5.13,5.39) \mathrm{b}$ & $5.76(5.46,6.06) \mathrm{a}$ & $0.63(-0.24,1.50) \mathrm{a}$ & $1.51(0.57,2.44) b$ \\
\hline $\mathrm{P}$ & $5.44(5.31,5.56) \mathrm{ab}$ & $5.59(5.29,5.89) \mathrm{a}$ & $1.88(1.01,2.75) \mathrm{a}$ & $\ldots$ \\
\hline \multicolumn{5}{|l|}{ Field 2} \\
\hline $\mathrm{LO} / \mathrm{LO}$ & $5.37(5.23,5.50) a b$ & $5.76(5.52,6.00) \mathrm{a}$ & $1.46(0.96,1.95) \mathrm{a}$ & $1.55(0.06,3.03) b$ \\
\hline $\mathrm{SB}$ & $5.46(5.32,5.60) \mathrm{a}$ & $5.71(5.47,5.95) \mathrm{a}$ & $1.04(0.54,1.54) \mathrm{a}$ & $1.38(-0.10,2.86) b$ \\
\hline $\mathrm{LO} / \mathrm{LO}(\mathrm{Fe} 1 / 6)$ & $5.32(5.19,5.46) a b$ & $5.50(5.26,5.74) \mathrm{a}$ & $1.04(0.54,1.54) \mathrm{a}$ & $3.05(1.56,4.53) a b$ \\
\hline $\mathrm{SB}(\mathrm{Fe} 1 / 6)$ & $5.40(5.26,5.54) a b$ & $5.48(5.24,5.72) \mathrm{a}$ & $1.04(0.54,1.54) \mathrm{a}$ & $1.88(0.39,3.36) \mathrm{ab}$ \\
\hline $\mathrm{LO} / \mathrm{LO}(\mathrm{Fe} 1 / 2)$ & $5.25(5.12,5.39) \mathrm{b}$ & $4.94(4.70,5.18) b$ & $1.25(0.75,1.75) \mathrm{a}$ & $4.00(2.52,5.49) \mathrm{a}$ \\
\hline $\mathrm{LO} / \mathrm{LO}(\mathrm{R})$ & $5.30(5.17,5.44) \mathrm{ab}$ & $5.61(5.37,5.85) \mathrm{a}$ & $1.04(0.55,1.54) \mathrm{a}$ & $2.42(0.94,3.90) \mathrm{ab}$ \\
\hline \multicolumn{5}{|l|}{ Field 3} \\
\hline $\mathrm{LO} / \mathrm{LO}$ & $5.45(5.23,5.67) \mathrm{a}$ & $5.46(5.33,5.60) \mathrm{a}$ & $1.25(0.91,1.58) \mathrm{a}$ & $1.29(1.05,1.53) \mathrm{a}$ \\
\hline $\mathrm{O} / \mathrm{O}$ & $5.51(5.29,5.73) \mathrm{a}$ & $5.40(5.26,5.53) \mathrm{a}$ & $0.75(0.42,1.09) \mathrm{b}$ & $1.25(1.01,1.50) \mathrm{a}$ \\
\hline $\mathrm{S}$ & $5.50(5.28,5.72) \mathrm{a}$ & $5.37(5.24,5.51) \mathrm{a}$ & $0.79(0.46,1.13) b$ & $1.13(0.89,1.37) \mathrm{a}$ \\
\hline $\mathrm{P}$ & $5.50(5.28,5.72) \mathrm{a}$ & $5.39(5.26,5.53) \mathrm{a}$ & $0.71(0.38,1.04) \mathrm{b}$ & $1.13(0.89,1.37) \mathrm{a}$ \\
\hline
\end{tabular}

${ }^{y}$ Within-factors for each response variable followed by the same letter are not significantly $(P>0.05)$ different according to Tukey's pairwise comparison. Point estimates in parentheses indicate $95 \%$ confidence intervals; $\ldots=$ not tested.

${ }^{\text {z }}$ LO, lopsided oat; V, woolly pod vetch; O, oat; P, potato; SB, sugar beet. Symbols: Fe, Ferosand; R, resistant potato ('Yukirasya'). 
In experiment 3 at Shihoro, lopsided oat treatment was more effective than the other treatments for suppressing PCS (Table 6). The disease severity following lopsided oat treatment was 33.6, which is significantly lower than that produced by the other treatments $(P<0.05)$. Disease incidence in the lopsided oat treatment plot was $71.0 \%$, which is significantly lower than for the other treatments $(P<0.001)$. Thus, lopsided oat treatment produced a significantly higher ratio of marketable tubers than the oat $(P=0.03)$ and continuous potato $(P<0.001)$ treatments, except for soybean. $S$. turgidiscabies was detected in the soybean- and potatotreated plots but not detected after harvesting in the lopsided oattreated plot. Although the disease incidence in individual plots was not significantly associated with soil $\mathrm{pH}$ or exchange acidity (Table 3), lopsided oat treatment tended to produce a higher exchange acidity compared with the other treatments (Table 4 ).

\section{Discussion}

Our study shows that using lopsided oat as green manure decreased PCS disease level in planters and commercial fields under regular agricultural production conditions. Furthermore, our results show that suppression level of PCS differed depending on the preceding crop type. Disease levels were lower following lopsided oat treatment than following oat and soybean or sugar beet cultivated as field rotation crops in Hokkaido, Japan.

Lopsided oat or woolly pod vetch treatment suppressed PCS more than oat treatment in plastic containers containing infested soil, whereas continuous cropping of potato resulted in the highest levels of disease (Fig. 1). Soybean green manure has been shown to reduce PCS $(29,33)$, whereas the use of rye either reduces the disease (22) or has no effect (35) on scab severity. Shiga and Suzuki (36) reported that the scab severity index tended to be reduced much more by treatment with lopsided oat, soybean, alfalfa, and hairy vetch than by control treatments, whereas scab severity after buckwheat and white mustard treatment increased significantly or occurred at the same rate as in the controls. Therefore, selecting green manure or cultivated crops for PCS disease management is an important consideration for potato production in an area with consistent scab disease.

We compared lopsided oat treatment with sugar beet and soybean as rotation crops in field experiments 2 and 3. Our results show that lopsided oat reduced the disease severity compared with the other crops. There was also a trend toward an increase in yield with lopsided oat, although no significant difference was observed. Sugar beet is an alternate host for S. turgidicabies; therefore, potato production following sugar beet cultivation may be plagued by serious disease outbreaks in areas infested with the pathogen. Although soybean green manure $(29,33)$ and soymeal (18) can reduce common potato scab, the effect of soybean cultivation on disease suppression was not necessarily evident in this experiment.

The susceptibility of soybean to the root lesion nematode should be considered when rotating crops. Although a population of $P$. penetrans was discovered only in field experiment 3 , the soil nematode density after lopsided oat treatment was the lowest among all treatments (data not shown). Gaylon et al. (10) found that densities of $P$. penetrans alone was not highly correlated with potato yields in a 3-year potato crop rotation but was consistently correlated with Verticillium wilt symptoms. In contrast, Mizukoshi et al. (24) found that potato yield decreased when the $P$. penetrans population exceeded 100 nematodes per $25 \mathrm{~g}$ of wet soil at harvesting. Mondia (25) reported that rotation with 'Saia' oat (two years) reduced $P$. penetrans numbers and increased potato tuber yields. Although most oat cultivars are good hosts $(19,41-43)$, the 'Hayoats' lopsided oat used in this study was developed and selected from an A. strigosa population with a low root egg ratio (egg/total infected nematodes) (45). Although the $P$. penetrans density in field experiments 1 and 2 was not investigated, it appears that the suppressive effect of lopsided oat on $P$. penetrans influenced the potato yield.

In field experiment 2, we evaluated the effect of lopsided oat treatment with Ferosand or a resistant potato cultivar on common scab in a field in which farmers were unable to produce potato tubers for food due to serious scab disease damage. Lopsided oat treatment with one-sixth and one-half of the Ferosand control (600 $\mathrm{kg} / \mathrm{ha}$ and $1.8 \mathrm{t} / \mathrm{ha}$, respectively) or a resistant potato cultivar was more effective than the use of lopsided oat alone. A slight decrease in potato tuber yield following treatment with one-half of the Ferosand control (1.8 t/ha) was observed compared with lopsided oat alone or one-sixth of the Ferosand control $(600 \mathrm{~kg} / \mathrm{ha})$, although no significant differences were observed. Optimization of the soil $\mathrm{pH}$ to $<5.2$ reduced scab incidence in many locations ( 31 )

Table 5. Effect of green manure treatment on common potato scab in field experiment $2(2000-01)^{\mathrm{w}}$

\begin{tabular}{|c|c|c|c|c|c|}
\hline Treatment $^{\mathrm{x}}$ & $\begin{array}{c}\text { Disease severity } \\
(\%)\end{array}$ & $\begin{array}{c}\text { Disease incidence } \\
(\%)\end{array}$ & $\begin{array}{c}\text { Marketable tuber } \\
(\%)\end{array}$ & $\begin{array}{l}\text { Potato yield } \\
\left(\mathrm{t} \mathrm{ha}^{-1}\right)\end{array}$ & $\begin{array}{c}\text { Streptomyces } \\
\text { turgidiscabies density }\end{array}$ \\
\hline $\mathrm{LO} / \mathrm{LO}$ & $15.2(10.7,21.2) b$ & $47.3(38.1,56.6) b$ & $88.9(78.6,94.6) b$ & $44.4(36.2,52.6) \mathrm{a}$ & ND \\
\hline SB & $27.8(20.8,36.2) \mathrm{a}$ & $69.5(60.8,77.0) \mathrm{a}$ & $66.2(48.5,80.3) \mathrm{c}$ & $40.7(32.5,48.9) \mathrm{ab}$ & $3.85(3.79,3.92) \mathrm{a}$ \\
\hline $\mathrm{LO} / \mathrm{LO}(\mathrm{Fe} 1 / 6)$ & $9.1(6.2,13.2) \mathrm{c}$ & $28.0(20.7,36.6) \mathrm{c}$ & $93.2(85.7,96.9) \mathrm{ab}$ & $43.4(35.2,51.6) \mathrm{ab}$ & ND \\
\hline $\mathrm{SB}(\mathrm{Fe} 1 / 6)$ & $28.2(21.0,36.7) \mathrm{a}$ & $64.9(55.6,73.3) \mathrm{a}$ & $69.1(51.6,82.4) \mathrm{c}$ & $47.1(38.9,55.3) \mathrm{a}$ & $3.70(3.63,3.76) b$ \\
\hline $\mathrm{LO} / \mathrm{LO}(\mathrm{Fe} 1 / 2)$ & $5.2(3.3,8.1) \mathrm{d}$ & $16.2(10.7,23.8) \mathrm{d}$ & $96.4(90.9,98.6) \mathrm{a}$ & $37.6(29.4,45.8) a b$ & ND \\
\hline $\mathrm{LO} / \mathrm{LO}(\mathrm{R})$ & $1.3(0.6,2.7) \mathrm{e}$ & $5.3(2.5,10.7) \mathrm{e}$ & $100^{z}$ & $33.1(24.9,41.3) b$ & ND \\
\hline
\end{tabular}

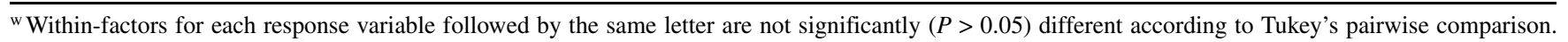
Point estimates in parentheses indicate $95 \%$ confidence intervals.

x Precrops in 2000 before potato. LO, lopsided oat and SB, sugar beet. Symbols: Fe, Ferosand; R, resistant potato ('Yukirasya') indicates treatment potato cultivation in 2001 .

${ }^{\mathrm{y}} \log _{10}(x+1)$ transformation; $x=\mathrm{CFU} / \mathrm{g}$ dry soil. ND, not detected.

${ }^{\mathrm{z}}$ Omitted from the statistic analysis because it was $100 \%$ with three replicates.

Table 6. Effect of green manure treatment on common potato scab in field experiment $3(2001-02)^{\mathrm{x}}$

\begin{tabular}{lccccc}
\hline Treatment & $\begin{array}{c}\text { Disease severity } \\
(\%)\end{array}$ & $\begin{array}{c}\text { Disease incidence } \\
(\boldsymbol{\%})\end{array}$ & $\begin{array}{c}\text { Marketable tuber } \\
(\boldsymbol{\%})\end{array}$ & $\begin{array}{c}\text { Potato yield } \\
\mathbf{t ~ h a}^{-1} \mathbf{)}\end{array}$ & $\begin{array}{c}\text { Streptomyces } \\
\text { turgidiscabies density }\end{array}$ \\
\hline $\mathrm{LO} / \mathrm{LO}$ & $33.6(27.8,40.0) \mathrm{c}$ & $71.0(54.1,83.5) \mathrm{a}$ & $51.3(40.6-61.9) \mathrm{a}$ & $41.0(36.2,45.8) \mathrm{a}$ & $\mathrm{ND}$ \\
$\mathrm{O} / \mathrm{O}$ & $38.8(32.4,45.6) \mathrm{b}$ & $86.5(74.6,93.3) \mathrm{b}$ & $40.3(30.0-51.5) \mathrm{b}$ & $33.9(29.1,38.7) \mathrm{b}$ & $\ldots$ \\
$\mathrm{S}$ & $40.0(33.6,46.7) \mathrm{b}$ & $85.1(72.7,92.4) \mathrm{b}$ & $43.7(33.4-54.6) \mathrm{ab}$ & $35.5(30.7,40.3) \mathrm{ab}$ & 1.01 \\
$\mathrm{P}$ & $46.0(39.2,52.9) \mathrm{a}$ & $86.9(75.3,93.5) \mathrm{b}$ & $36.5(26.8-47.5) \mathrm{b}$ & $36.5(31.7,41.3) \mathrm{ab}$ & 1.01 \\
\hline
\end{tabular}

${ }^{\mathrm{x}}$ Within-factors for each response variable followed by the same letter are not significantly $(P>0.05)$ different according to Tukey's pairwise comparison. Point estimates in parentheses indicate $95 \%$ confidence intervals.

${ }^{y}$ Precrops in 2001 before potato. LO, lopsided oat; O, oat; S, soybean; P, potato.

${ }^{\mathrm{z}} \log _{10}(x+1)$ transformation; $x=\mathrm{CFU} / \mathrm{g}$ dry soil. ND, not detected; ..., not tested. 
but an excessive reduction in soil $\mathrm{pH}$ may be harmful to plants in crop rotations. The potato yield under these conditions was likely affected by the soil $\mathrm{pH}$ throughout the growing season, because the soil $\mathrm{pH}$ was very low (4.94) at harvest time (Table 4). In contrast, exchange acidity following lopsided oat treatment was slightly higher than that with sugar beet, oat, and soybean. These results are consistent with a report from Suzuki and Shiga (39) showing that exchange acidity following lopsided oat cultivation was higher than after several preceding crops. Because the severity of PCS is reduced when the exchange acidity is high (38), it is presumed that this is one of the factors involved in the suppressive effect of lopsided oat. In all of our field experiments, densities of S. turgidiscabies in the lopsided oat treatments were lower than for the other treatments (Table 2) and was not detected in field experiments 2 and 3 (Tables 5 and 6). It is likely that the disease-suppressive effect of lopsided oat treatment is a result of a decrease in pathogen density, because $S$. turgidscabies levels in the soil were significantly correlated with disease incidence in field experiment 1 .

In conclusion, fallow cultivation (twice per year) of lopsided oat produced more productive potato tubers and lessened PCS damage compared with soybean and sugar beet. In seriously diseased areas, a combination of lopsided oat with one-sixth of the Ferosand control volume (reaching pH 5.0 after dissemination) or a resistant potato cultivar was more effective than Ferosand alone because of increased productivity without low soil $\mathrm{pH}$. In these experiments, lopsided oat was cultivated twice per year. Wiggins and Kinkel (44) studied the effects of green manure and crop sequence on potato disease and found that PCS was not affected significantly by green manure because of intense disease severity. They suggested that green manure might be most effective for suppressing scab disease when the initial disease pressure is low or following multiple green manure cycles. Although we investigated lopsided oat cultivation once per year in plastic planters containing $S$. turgidiscabies-infested soil, the suppressive effect on PCS was insufficient (F. Sakuma, data not shown). Thus, field experiments using a single crop of lopsided oat should be performed in the future.

The use of green manure is a practical management option for potato growers in Hokkaido, Japan. Many growers already plant fall green manure after harvesting winter wheat due to the benefits conferred by the physical modification of soil structure as well as increased organic matter and nutrients. These results indicate that lopsided oat treatment effectively reduced PCS in naturally infested fields and increased the mean tuber yield without removing fields from production. Investigations of lopsided oat as green manure to suppress other soilborne diseases have been conducted $(14,15,27,46)$. With the withdrawal of many chemical pesticides from the market and rising concern over their use, control strategies such as the use of lopsided oat for green manure deserve further investigation. More broadly, our results suggest that integrated lopsided oat cultivation may help suppress a diverse collection of pathogens and diseases.

\section{Acknowledgments}

This work was supported in part by a Grant-in-Aid from the Society for Techno-innovation of Agriculture, Forestry and Fisheries (STAFF). We thank T. Mori and S. Tani for their help in establishing and preserving the field plots.

\section{Literature Cited}

1. Abdallahi, M. M., and N'Dayegamiye, A. 2000. Effects of green manures on soil physical and biological properties and on wheat yields and $\mathrm{N}$ uptake. Can. J. Soil Sci. 80:81-89.

2. Al-Khaib, K., Libbey, C., and Boydston, R. 1997. Weed suppression with Brassica green manure crops in green pea. Weed Sci. 45:439-445.

3. Ananth, C. V., and Kleinbaum, D. G. 1997. Regression models for ordinal responses: A review of methods and applications. Int. J. Epidemiol. 26:1323-1333.

4. Bate, D., and Maechler M. 2009. lme4: Linear Mixed-Effects Models Using S4 Classes. R Package, version 0.999375-32.

5. Bolker, B. M., Brooks, M. E., Clark, C. J., Geange, S. W., Poulsen, J. R., Stevens, M. H. H., and White, J.-S. S. 2008. Generalized linear mixed models: A practical guide for ecology and evolution. Trends Ecol. Evol. 24:127135 .
6. Devis, J. R., Huisman, O. C., Westermann, D. T., Hafez, S. L., Everson, D. O., Sorensen, L. H., and Schneider, A. T. 1996. Effects of green manures on Verticillium wilt of potato. Phytopathology 86:444-453.

7. Dobson, A. J. 2002. An Introduction to Generalized Linear Models, 2nd ed. Chapman \& Hall.

8. Faraway, J. J. 2006. Extending the Linear Models with R: Generalized Linear, Mixed Effects and Nonparametric Regression Models. Chapman \& Hall/CRC.

9. Garrett, K. A., Madden, L. V., Hughes, G., and Pfender, W. F. 2004. New applications of statistical tools in plant pathology. Phytopathology 94:9991003

10. Gaylon, D. M., Ann, E. M., Jun, Z., and Larry, K. B. 2002. Population dynamics and distribution of root lesion nematode (Pratylenchus penetrans) over a three-year potato crop rotation. Agron. J. 94:1146-1155.

11. Hothorn, T., Bretz, F., and Westfall, P. 2008. Simultaneous inference in general parametric models. Biometrical J. 50:346-363.

12. Iketani, S., Fujita, R., Itoh, T., and Iritani, M. 2004. A new potato variety Hokuiku 7 with high resistance to common scab. In: Proc. Int. Potato Scab Symp. (IPSS2004). S. Naito, N. Kondo, S. Akino, A. Ogoshi, and F. Tanaka eds. Sapporo, Japan.

13. Kobayashi, A. 2004. Breeding of common scab resistant variety in Japan. In: Proc. Int. Potato Scab Symp. (IPSS2004). S. Naito, N. Kondo, S. Akino, A. Ogoshi, and F. Tanaka, eds. Sapporo, Japan.

14. Komatsu, T., Takabayashi, T., and Yamazaki, H. 2003. Control effect of Verticillium black spot of Japanese radish by applying green manure (Abstract in Japanese). Jpn. J. Phytopathol. 69:283-284.

15. Konagai, K., Sakamoto, K., Usami, T., Amemiya, Y., and Shishido, M 2005. Effect of wild oats green manure on soil microflora and diseases of tomato (in Japanese with English summary). Jpn. J. Phytopathol. 71:101110 .

16. Kritzman, G., and Grinstein, A. 1991. Formalin application against soilborne Streptomyces. Phytoparasitica 19:248

17. Lambert, D. H., and Loria, R. 1989. Streptomyces scabies sp. nov. nom Rev. Int. J. Syst. Bacteriol. 39:387-392.

18. Lazarovits, G., Conn, K. L., and Potter, J. 1999. Reduction of potato scab, Verticillium wilt, and nematodes by soymeal and meat and bone meal in two Ontario potato fields. Can. J. Plant Pathol. 21:345-353.

19. MacDonald, D. H., and Mai, W. F. 1963. Suitability of various cover crops as hosts for the lesion nematode, Pratylenchus penetrans. Phytopathology 53:730-731.

20. Madden, L. V., Turechek, W. W., and Nita, M. 2002. Evaluation of generalized linear mixed models for analyzing disease incidence data obtained in designed experiments. Plant Dis. 86:316-325.

21. Matsumoto, K. 1979. Spore forming medium of potato scab pathogen and long time storage method for pathogen. Plant Prot. 33:461-463. (In Japanese)

22. Millard, W. A. 1923. Common scab of potatoes. II. Ann. Appl. Biol. 10:7088

23. Miyajima, K., Tanaka, F., Takeuchi, T., and Kuninaga, S. 1998. Streptomyces turgidiscabies sp. nov. Int. J. Syst. Bacteriol. 48:495-502.

24. Mizukoshi, T., Baba, S., Matsui, K., Nakagawa, R., Higuchi, Y., and Yamada, N. 2003. Damage to field crop by Pratylenchus penetrans in the Tokachi district Hokkaido and the effect of antagonistic plant. Jpn. J. Nematol. 33:86-87. (Abstr. in Japanese)

25. Mondia, J. A. 2006. Management of lesion nematodes and potato early dying with rotation crops. J. Nematol. 38:442-448.

26. Muehlchen, A. M., Rand, R. E., and Parke, J. L. 1990. Evaluation of crucifer green manures for controlling Aphanomyces root rot of peas. Plant Dis. 74:651-654.

27. Murakami, H., Tsushima, S., Akimoto, T., and Shishido, Y. 2001. Reduction of spore density of Plasmodiophora brassicae in soil by decoy plants. J. Gen. Plant Pathol. 67:85-88.

28. Nasir, N., Pittaway, P. A., and Pegg, K. G. 2003. Effect of organic amendments and solarisation of Fusarium wilt in susceptible banana plantlets, transplanted into naturally infested soil. Aust. J. Agric. Res. 54:251-257.

29. Oswald, J. W., and Lorenz, O. A. 1956. Soybeans as a green manure crop for the prevention of potato scab. (Abstr.) Phytopathology 46:22.

30. Pinheiro, J., Bates, D., DebRoy, S., Sarkar, D., and the R Core team. 2009. nlme: Linear and Nonlinear Mixed Effects Models. R Package, version 3.196.

31. Powelson, M. L., Johnson, K. B., and Rowe, R. C. 1993. Management of diseases caused by soilborne pathogens. Pages 149-158 in: Potato Health Management. American Phytopathological Society, St. Paul, MN.

32. R Development Core Team 2009. R: A Language and Environment for Statistical Computing. R Foundation for Statistical Computing, Vienna.

33. Rouatt, J. W., and Atkinson, R. G. 1950. The effect of the incorporation of certain cover crops on the microbiological balance of potato scab infested soil. Can. J. Res. (Sect. C) 28:140-152.

34. Saigusa, M., Shoji, S., and Takahashi, T. 1980. Plant root growth in acid Andosols from northwest Japan; 2. Exchange acidity Y1 as a realistic measure of aluminum toxicity potential. Soil Sci. 130:242-250.

35. Sandford, G. B. 1926. Some factors affecting the pathogenicity of Actinomyces scabies. Phytopathology 16:525-547.

36. Shiga, H., and Suzuki, K. 2004. Effect of soil acidity, organic soil amend- 
ment and green manure on potato scab. In: Proc. Int. Potato Scab Symp. (IPSS2004). S. Naito, N. Kondo, S. Akino, A. Ogoshi, and F. Tanaka, eds. Sapporo, Japan.

37. Shimono, K. 1990. Effects of soil $\mathrm{pH}$ on the growth and yield of field crops in wet Andosols. J. Sci. Soil Manure. 61:8-15. (In Japanese)

38. Suzuki, K., and Shiga, H. 2001. Effect of organic matter application on potato scab. Jpn. J. Soil Sci. Plant Nutr. 72:287-290. (In Japanese)

39. Suzuki, K., and Shiga, H. 2002. Effect of exchange acidity and preceding crops on potato scab. Abstr. Annu. Meet. Jpn. J. Soil Sci. Plant Nutr. 48:202. (Abstr. in Japanese)

40. Tanaka, F. 2000. Identification, quantification of potato scab pathogens and control of the disease by changing soil environment. Rep. Hokkaido Prefectural Agric. Exp. Stn. No. 96:1-66. (In Japanese with English summary)

41. Townshend, J. L. 1989. Population densities of four species of root-lesion nematodes (Pratylenchus) in the oat cultivars, Saia and OAC Woodstock. Can. J. Plant Sci. 69:903-905.
42. Townshend, J. L., and Potter J. W. 1976. Evaluation of forage legumes, grasses, and cereals as hosts of forage nematodes. Nematologia 22:196-201.

43. Vrain, T., Deyoung, R., Hall, J., and Freyman, S. 1996. Cover crops resistant to root-lesion nematodes in raspberry. Hortscience 31:1195-1198.

44. Wiggins, B. E., and Kinkel, L. L. 2005. Green manures and crop sequences influence potato diseases and pathogen inhibitory activity of indigenous streptomycetes. Phytopathology 95:178-185.

45. Yamada, E. 1998. Suppressive effect on nematode of green manure crop (Hayoat). Grass Hortic. 46:8-14. (In Japanese)

46. Yamada, E., Sakuma, F., Hashizume, K., Takahashi, M., Fukuhara, Y., Kobayashi, K., and Kondo, N. 2005. Seasonal occurrence of Pratylenchus penetrans, Heterodera glycines and Phialophora gregata f. sp. adzukicola as affected by the cultivation of green manure crops. Jpn. J. Nematol. 35:79-86. (In Japanese with English summary)

47. Yee, T. W. 2009. VGAM: Vector Generalized Linear and Additive Models. R Package, version 0.7-9. 